Shaposhnykov K. S., Doctor in Economics, Professor

Black Sea Research Institute of Economy and Innovation

Odessa, Ukraine

DOI: https://doi.org/10.30525/978-9934-26-080-3-8

\title{
STAGES OF ESTABLISHMENT AND DEVELOPMENT OF THE DIGITAL ECONOMY IN UKRAINE
}

Modern digital technologies are significantly changing the socioeconomic and social relations, in this regard, a new - information society and, accordingly, a new stage of economic development - the digital economy. The formation of the digital economy is an important stage in the development of society, which allows to expand the information space, use the intellectual potential and knowledge of man, creating the factors of a stable safe social environment in the future.

The ontology of the interpretation of the digital economy is similar to the evolution of the concept of «information economy»: since its inception, the digital economy was seen as a process of production, sale and supply of products using computer networks (1995); at the stage of formation - from the definition of the digital economy as the integration of supporting digital infrastructure, e-business and e-commerce (2001) to its definition as the formation of a network of economic entities that create and exchange digital assets (virtual assets) through the spread and development of the Internet (2009); at the stage of development, the digital economy is seen as the transformation of traditional and information economies through the transfer of information resources and knowledge to the digital platform for further dissemination and use (2017), as well as the formation of socio-economic and cultural relations through the use of digital information -communication technologies (2018); the stage of transformation of the digital economy is expected during 2023-2025.

It is proposed to consider the digital economy not as a separate revolutionary stage of economic development, but as a transformation of the information economy due to the development of the IT sphere, 
the formation of information and communication (later digital) infrastructure, the emergence of artificial intelligence, virtualization of international markets.

In today's conditions, the digital economy of Ukraine is the basis for the development of public administration, economy, business, social sphere and society in general, and it's security is the basis of national security, social security and competitiveness of domestic enterprises, organizations and institutions. In order to develop the digital economy of Ukraine, its further transformation into the latest forms of transformation of the economic system requires effective state support to ensure proper functioning, its protection at the macro and macro levels, stimulating its development and overcoming the «digital divide». Therefore, the basis of the concept of «digitalization» of Ukraine should be the formation of the latest form of «digital relationship» of the triad «person - enterprise - state», which in turn implies the need to develop and develop new scientific paradigms for their management.

The role of information resources and information and communication systems as the basis for the formation of a new «digital» society, the infrastructure of which is intelligent computing, is growing. The digital transformation of society leads to the reformatting of all types of social relations, especially governance.

The leaders in digital production are digital and nanotechnology, banking and retail, and it is they who are now benefiting most from the digital transformation. For telecommunications and hotel business, it is necessary to change the business model and attract new management methods.

Information technologies are becoming global in nature, covering all spheres of life, forming the information unity of all human civilization. The current stage of development of society is characterized by the growing role of the information sphere, is a set of information, information infrastructure of entities that collect, form, disseminate and use information. As a system-forming factor in society, the information sphere actively influences the state of political, economic, defense and other components of the country's security. National security is 
dependent on information security, and in the process of digitalization of the economy and informatization of public relations, this dependence becomes especially important.

\section{References:}

1. Vail P., Vornes S. (2019) Tsyfrovaia transformatsyia byznesa: Yzmenenye byznes-modely dlia orhanyzatsyy novoho pokolenyia. Moskow: Alpyna Pablysher, $257 \mathrm{p}$.

2. Huzhva V.M. Tsyfrova transformatsiia ekonomiky: vymiriuvannia ta otsinka rezultativ. URL: https://ir.kneu.edu.ua/bitstream/handle/2010/31538/ZE_2019_48.pdf ?sequence $=3$.

3. Derhachova H., Koleshnia Ya. (2020) Tsyfrova transformatsiia biznesu: sutnist, oznaky, vymohy ta tekhnolohii. Ekonomichnyi visnyk NTUU «KPI», no. 17, pp. 280-290. URL: http://ev.fmm.kpi.ua/article/view/216367.

4. Kruhlov V.V. Tsyfrova transformatsiia yak sposib pobudovy smart-suspilstva. URL: https://conf.ztu.edu.ua/wp-content/uploads/2021/01/335.pdf.

5. Lisova R.M. (2020) Tsyfrova transformatsiia ta stratehichne upravlinnia biznes-modeliamy. Suchasnyi menedzhment: tendentsii, problemy ta perspektyvy rozvytku: tezy dopovidei uchasnykiv V Mizhnarodnoi naukovo-praktychnoi konferentsii molodykh vchenykh i studentiv. Dnipro, 23 kvitnia 2020 r. Dnipro: Universytet imeni Alfreda Nobelia, pp. 88-90.

6. Pizhuk O.I. (2020) Tsyfrova transformatsiia ekonomiky Ukrainy: obmezhennia ta mozhlyvosti: monohrafiia / Olha Ivanivna Pizhuk; Universytet derzhavnoi fiskalnoi sluzhby Ukrainy. Irpin, 504 p.

7. Rudenko M.V. (2018) Tsyfrovizatsiia ekonomiky: novi mozhlyvosti ta perspektyvy. Ekonomika ta derzhava, no. 11, pp. 61-65. URL: http://www.economy.in.ua/pdf/11_2018/13.pdf. 